\title{
The Rule of International (Environmental) Law and Complex Problems
}

\author{
[Forthcoming in Heike Krieger/Georg Nolte/Andreas Zimmermann (eds), \\ The International Rule of Law: Rise or Decline?]
}

\author{
CJutta Brunnée* \\ Faculty of Law, University of Toronto
}

\begin{abstract}
An example of a complicated system is an automobile, composed of thousands of parts whose interactions obey precise, simple, known and unchanging cause-andeffect rules.
\end{abstract}

An ensemble of cars travelling down a highway, by contrast, is a complex system. Drivers interact and mutually adjust their behaviours based on diverse factors such as perceptions, expectations, habits, even emotions ... actual traffic flow cannot be predicted with certainty. No one driver is in control and there is no single destination. ${ }^{1}$

\section{Introduction}

It is perhaps no coincidence that the editors of this volume on the "rise or decline" of the international rule of law asked an international environmental lawyer to assess international law's capacity to tackle complex problems. After all, it may seem obvious that many environmental problems qualify as "complex," and that an international environmental problem is all the more complex, due to the need to involve several, sometimes even all, states in problem-solving and to shift conduct by, as well as address impacts on, a wide range of non-state actors as well. However, understanding complexity, and the distinctive features of complex problems, is more complicated than meets the eye. Indeed, as the opening quote serves to illustrate, there is a difference between a merely complicated and a complex issue. This difference, in turn, has significant implications for efforts to address complex problems, and for understanding the role of international law, and the international rule of law, in doing so.

\footnotetext{
* Professor of Law and Metcalf Chair in Environmental Law, Faculty of Law University of Toronto. I thank Sarah Mason-Case for her helpful comments on a draft version of this chapter.

${ }^{1}$ OECD Global Science Forum, Applications of Complexity Science for Public Policy: New Tools for Finding Unanticipated Consequences and Unrealized Opportunities (September 2009), at 1-2; at https://www.oecd.org/science/sci-tech/43891980.pdf (accessed April 11, 2017).
} 
Complexity thinking has its origins in the natural sciences, ${ }^{2}$ notably mathematics and physics, where it emerged as a reaction to the dominant Enlightenment paradigms associated with Newton and Descartes. ${ }^{3}$ The common theme in the many strands of complexity (or "complex systems") theory is that "the whole is greater than the sum of its parts." ${ }^{4}$ The "[p]arts and the whole co-constitute one another," such that "complexity neither denies an autonomous existence to the parts composing the system nor seeks to dissolve them into an overarching determining structure. ${ }^{5}$ Hence, while a complicated system or problem can be understood through conventional scientific approaches, a complex one requires an approach that can accommodate "non-linear and collective patterns of behaviour." 6

In the latter part of the twentieth century, complexity thinking was also taken up in the social sciences. A variety of disciplines, ranging from psychology to urban planning, have sought to identify the traits that render complex, or even "wicked," problems so resistant to resolution: multiple variables of a problem situation; interconnectedness of the variables; dynamism of the problem situation and variables; incomplete knowledge or understanding of the problem situation; and polycentric nature of the situation. ${ }^{7}$ After the end of the Cold War, complexity thinking gained currency in the International Relations (IR) literature, ${ }^{8}$ coinciding with the discipline's increased focus on processes of globalization. ${ }^{9}$ IR scholars have pursued various lines of inquiry, including into the notions of complex interdependence, ${ }^{10}$ cooperation, $^{11}$ learning, ${ }^{12}$ and socialization. ${ }^{13}$ The overarching insight IR scholars

\footnotetext{
${ }^{2}$ See Warren Weaver, "Science and Complexity," (1948) 36 American Scientist 536-544.

${ }^{3}$ See Emilian Kavalski, "The fifth debate and the emergence of complex international relations theory: notes on the application of complexity theory to the study of international life," (2007) 20 Cambridge Review of International Affairs 435-454, at 437; Antoine Bousquet and Simon Curtis, "Beyond models and metaphors: complexity theory, systems thinking and international relations," (2011) 24 Cambridge Review of International Affairs 43-62, at 44.

${ }^{4}$ See Femke Reitsma, "A response to simplifying complexity," (2003) 34 Geoforum 13-16, at 13.

${ }^{5}$ Bousquet and Curtis, "Beyond models and metaphors," note 2, at 45.

${ }^{6}$ OECD Global Science Forum, Applications of Complexity Science for Public Policy, note 1, at 2.

7 See e.g. Joachim Funke, "Complex Problem Solving," in Norbert M. Seel (ed.), Encyclopedia of the Sciences of Learning, vol. 38 (Heidelberg: Springer Verlag 2012), 682-685, at 683. The phrase "wicked problem" stems from an influential article by two urban planners: Horst W.J. Rittel and Melvin M. Webber, "Dilemmas in a general theory of planning," (1973) 4 Policy Sciences 155-169.

8 See e.g. John Lewis Gaddis, "International Relations Theory and the End of the Cold War," (1992/93) 17 International Security 5-58;

${ }^{9}$ Bousquet and Curtis, "Beyond models and metaphors," note 2, at 48. But see already John Ruggie, "Complexity, Planning, and Public Order," in Todd LaPorte (ed.), Organized Social Complexity: Challenge to Politics and Policy (Princeton, NJ: Princeton University Press, 1975), 119-150.

${ }^{10}$ See Joseph Nye, Understanding International Conflict (New York: Harper Collins, 1993), at 169.

${ }^{11}$ See Robert Axelrod, The Complexity of Cooperation (Princeton, NJ: Princeton University Press, 1997).

${ }^{12}$ See Alexander Wendt, Social Theory of International Politics (Cambridge: Cambridge University Press, 1999), at 170.

${ }^{13}$ See Trine Flockhart, “Complex Socialization," (2006) 12 European Journal of International Relations 89-118
} 
have derived from these inquiries is that complexity requires analysts as well as policy-makers to adopt relational and process-focused approaches that are sensitive to "organizational patterns, networked relationships and historical context," and that privilege "dynamic flux over stable essences." ${ }^{14}$ Legal scholarship has been considerably slower to engage with complexity theory, ${ }^{15}$ and its application to international law has remained sporadic. ${ }^{16}$ Nevertheless, some authors have sought to understand international law itself as "a complex system that emerges from the actions and interactions of States and other ... actors in their international relations."17

Against this backdrop, I return to my starting proposition. International environmental problems, in particular global climate change, are now widely approached as complex problems. ${ }^{18}$ To put it in the terms of the examples in the opening quote: they are increasingly thought of as "traffic," rather than "cars." Indeed, the complexity of tackling climate change far exceeds that of managing "traffic," seeing as it involves not only the coordination of human conduct, but requires consideration of the problem's environmental, scientific, economic, social, security and equity dimensions. Accordingly, global climate change has been labelled a "super-wicked" problem, ${ }^{19}$ and complexity thinking is increasingly prominent in the global environmental governance literature. It has been argued, for example, that the UN Framework Convention on Climate Change (FCCC ${ }^{20}$ should be understood "less as an authority that attempts to govern climate change," and more as interacting with multiple other parts of a complex

14 Bousquet and Curtis, "Beyond models and metaphors," note 2, at 45, 48 and 49. And see Australian Public Service Commission, Tackling Wicked Problems: A Public Policy Perspective (2007), at http://www.enablingchange.com.au/wickedproblems.pdf (accessed April 12, 2017).

15 See e.g. J.B. Ruhl, "Thinking of Environmental Law as a Complex Adaptive System: How to Clean up the Environment by Making a Mess of Environmental Law," (1997) 34 Houston Law Review 933-1002; Julian Webb, "Law, Ethics, and Complexity: Complexity Theory \& the Normative Reconstruction of Law," (2005) 52 Cleveland State Law Review 227.

${ }^{16}$ See e.g. Mark Chinen, "Complexity Theory and the Horizontal and Vertical Dimensions of State Responsibility," (2014) 25 European Journal of International Law 703-732; Joost Pauwelyn, "At the Edge of Chaos? Foreign Investment Law As A Complex Adaptive System, How It Emerged And How It Can Be Reformed" (January 24, 2014); at https://ssrn.com/abstract=2271869 (accessed April 12, 2017); Steven Wheatley, "The Emergence of New States in International Law: The Insights from Complexity Theory," (2016) 15 Chinese Journal of International Law 579606.

${ }^{17}$ Wheatley, ibid., at 581.

${ }^{18}$ See OECD Global Science Forum, Applications of Complexity Science for Public Policy, note 1, at 12.

${ }^{19}$ See Kelly Levin, Benjamin Cashore, Steven Bernstein and Graeme Ault, "Overcoming the tragedy of super wicked problems: constraining our future selves to ameliorate global climate change," (2012) 45 Policy Science 123-152, at 127-129 (identifying additional features that render complex problems "super wicked": time is running out; those seeking to end the problem are also causing it; no central authority; and policies discount the future irrationally). ${ }^{20}$ UN Framework Convention on Climate Change (FCCC), reprinted in (1992) 31 ILM 849. 
climate governance system. ${ }^{21}$ International environmental law scholarship has only begun to build on these insights. In one recent article, for example, the field as a whole was described as a complex system, composed of a decentralized network of interacting norms, treaties and institutions that continuously adapt to external change. ${ }^{22}$ It is this nascent strand of the literature that I aim to extend in this chapter, focusing on the role of international law in tackling global climate change.

Complexity thinking underscores that, while international law must provide stability to interactions around global climate change, it must also be flexible and highly adaptable. ${ }^{23}$ But what are the implications of this functional imperative for the international rule of law? The emergence and evolution of the UN climate regime coincides with the period since the end of the Cold War that the editors of this volume have identified for the purposes of assessing whether the international rule of law has been on the "rise" or in "decline." Global climate law, then, lends itself to exploring the trajectory of international law in its encounter with complexity. The 1992 Rio Conference on Environment and Development, during which the FCCC was adopted, has been identified as the high point of international environmental lawmaking activity, ${ }^{24}$ with treaty-making slowing thereafter, ${ }^{25}$ or even "stagnating." ${ }^{26}$ However, for present purposes, the most important shift in the treaty context may not have been the decrease in the adoption of new multilateral environmental agreements (MEAs), but the shift to the adoption of amendments to existing agreements. ${ }^{27}$ Furthermore, the perhaps most significant trend in international environmental law-making has been the rise of a spectrum of more or less formal

\footnotetext{
${ }^{21}$ See Michele Betsill et al., "Building Productive Links Between the UNFCCC and the Broader Global Climate Governance Landscape," (2015) 15 Global Environmental Politics 1-10.

22 Rakhyun E. Kim and Brendan Mackey, "International environmental law as a complex adaptive system," (2014) 14 International Environmental Agreements 5-24.

${ }^{23}$ See also Harro van Asselt, "Between the Devil and the Deep Blue Sea: Enhancing Flexibility in International Climate Change Law," (2014) 45 Netherlands Yearbook of International Law 255-286.

${ }^{24}$ Between 1990 and 1992, 106 multilateral environmental agreements (MEAs) were concluded. By comparison, between 1970 and 1972, 33 MEAs were concluded, and between 1980 and 1982, 45 MEAs were concluded. In turn, between 2000 and 2002, 88 MEAs were concluded and between 2010 and 2012, 57 MEAs were concluded. See Ronald B. Mitchell, International Environmental Agreements Database Project (Version 2014.3) (2002-2015), http://iea.uoregon.edu/page.php?query=summarize by year\&yearstart=1950\&yearend=2012\&inclusion=MEA (accessed April 3, 2016) (using the notion of MEA to encompass new treaties, protocols to existing treaties, and amendments to existing treaties).

${ }^{25}$ See Stacy Vandeveer, "Green Fatigue," (2003) 27 Wilson Quarterly 55-59.

${ }^{26}$ See generally Joost Pauwelyn, Ramses A. Wessel, and Jan Wouters, "When Structures Become Shackles: Stagnation and Dynamics in International Law-making," (2015) 25 European Journal of International Law 733-63.

${ }^{27}$ Consider these numbers, compiled on the basis of the database maintained by Mitchell, note 24: 1970-1972: 33 MEAs (21 new, 3 protocols, 9 amendments); 1980-1982: 45 MEAs (19 new, 9 protocols, 17 amendments); 19901992: 106 MEAs (50 new, 21 protocols, 44 amendments); 2000-2002: 88 MEAs (37 new, 15 protocols, 47 amendments); and 2010-2012: 57 MEAs (11 new, 10 protocols, 36 amendments).
} 
amendment processes, and of various modes of informal standard-setting under the auspices of MEAs, including the FCCC. ${ }^{28}$

Is this rise of "informality" indicative of a "decline" of the international rule of law? Even if the yardstick were a decrease in recourse to formally binding rules, the patterns of international environmental lawmaking activity may not suggest a "decline," but rather of "treaty saturation," which in turn accounts for the shift to amendments of and and standard-setting under existing treaties. ${ }^{29}$ I argue that, in any case, the "hard" vs. "soft" law distinction is not the most informative metric when it comes to exploring the trajectory of the international rule of law. In offering an alternative framework, I build on the editors' proposition that the international rule of law presupposes a system of distinctly legal norms that "conforms to a certain standard." ${ }^{30}$ Analytic attention, I suggest, is most fruitfully directed to the distinctive traits of legal norms and practices, traits that transcend traditional conceptions of formality and informality.

I begin by highlighting the main features of climate change as a complex policy challenge. Next, drawing on the interactional account of international law that I have developed elsewhere, I set out what I understand to be the key traits of legality and the rule of law in the international context. ${ }^{31}$ I then explore the evolution of customary, "soft" and treaty-based international environmental law. I focus primarily on how treaty-based law has evolved to grapple with complexity on the one hand, and meeting the demands of the rule of law on the other. The 2015 Paris Agreement, ${ }^{32}$ which was adopted under the auspices of the FCCC and employs an unprecedented range of legal "modes," provides an excellent opportunity to reflect on this question.

\footnotetext{
${ }^{28}$ See Jutta Brunnée, "COPing with Consent: Law-making under Multilateral Environmental Agreements," (2002) 15 Leiden Journal of International Law 1-52. And see Pauwelyn et al., "When Structures Become Shackles," note 26, at 740 .

${ }^{29}$ See note 27.

${ }^{30}$ See Heike Krieger and Georg Nolte, "The International Rule of Law - Rise or Decline? Points of Departure," (October 2016; on file with author), at 10.

${ }^{31}$ Jutta Brunnée and Stephen J. Toope, Legitimacy and Legality in International Law: An Interactional Account (Cambridge: Cambridge University Press, 2010); and Jutta Brunnée and Stephen J. Toope, "Interactional Legal Theory, the International Rule of Law and Global Constitutionalism," in Anthony F. Lang and Antje Wiener (eds.), Handbook of Global Constitutionalism (Cheltenham: Edward Elgar Publishing, forthcoming October 2017).

32 FCCC, Decision 1/CP.21 Adoption of the Paris Agreement, UN Doc. FCCC/CP/2015/10/Add., 1 Annex (Paris Agreement) (29 January 2016).
} 


\section{Climate Change as a Complex Problem}

Climate change, with its potential to disrupt natural, economic, and social systems on Earth, represents a grave threat to humanity and demands a determined response. But, as a policy challenge, climate change eludes easy categorization - it is not one problem, but a cluster of interrelated problems.

As an environmental problem, climate change is planetary in scope and, due to its long-term and potentially irreversible consequences, intergenerational in its impacts. ${ }^{33}$ It is caused by a wide range of production and consumption processes, and its effects are felt around the globe. For this reason alone, climate change is a complex collective action problem. It can be managed only if all states, or at least the major greenhouse gas emitters, cooperate in promoting costly shifts in their economic and energy systems. These challenges are compounded by the fact that far-reaching decisions must be made under conditions of scientific uncertainty and evolving scientific knowledge. ${ }^{34}$

Economic challenges go hand-in-hand with the environmental ones. The effects of climate change entail potentially significant economic costs, ranging from damage caused by extreme weather events, to the need to adapt infrastructure, to effects on coastal cities and other low-lying areas around the world, to shifting vegetation patterns and spread of viruses and species. ${ }^{35}$ In turn, mitigation of climate change involves costly shifts in production and consumption processes, and the projected global shift away from fossil fuels already has precipitated concerns over the future of resource-based national economies and carbon-based industrial sectors, including concerns over "stranded assets." 36

\footnotetext{
${ }^{33}$ See Richard Lazarus, "Super Wicked Problems and Climate Change: Restraining the Present to Liberate the Future," (2009) 94/5 Cornell Law Review 1153-1233.

${ }^{34}$ See Daniel Bodansky, Jutta Brunnée and Ellen Hey, 'International Environmental Law: Mapping the Field', in Daniel Bodansky, Jutta Brunnée and Ellen Hey (eds), Oxford Handbook of International Environmental Law (Oxford University Press, 2007) 1, 7-8 (on uncertainty in international environmental law).

${ }^{35}$ See Richard S.J. Tol, "The Economic Effects of Climate Change," (2009) 23 Journal of Economic Perspectives 2951.

${ }^{36}$ See e.g. Mark Carney, "Breaking the tragedy of the horizon - climate change and financial stability," Speech given at Lloyd's of London, 29 September 2015, at <http://www.bankofengland.co.uk/publications/Pages/speeches/2015/844.aspx> (accessed March 27, 2016).
} 
Climate change also raises security concerns. For some countries, like small island states, it poses an existential threat. ${ }^{37}$ For others, its physical effects might endanger human settlements, supplies of food, water or energy, or economic stability. ${ }^{38}$ These effects can exacerbate humanitarian crises, promote state failures and border disputes, and produce more conventional threats to national and international security. In 2004, then Chief Scientific Adviser to the Blair Government, David King, made headlines by saying that he considered climate change to be "the most severe problem that we are facing today more serious even than the threat of terrorism." ${ }^{39}$ Today, roughly $70 \%$ of states explicitly consider climate change to be a national security concern, acting as a "threat multiplier," or an "accelerant of instability." 40

Climate change furthermore raises difficult questions of equity and global environmental justice. ${ }^{41}$ Historically, emissions of greenhouse gases have been far greater in the industrialized world. ${ }^{42}$ But, by 2012, developing countries generated more than half of the world's carbon dioxide $\left(\mathrm{CO}_{2}\right)$ emissions, with China and India alone accounting for one-third. ${ }^{43}$ Thus, although the $\mathrm{CO}_{2}$ emissions of most industrialized countries still significantly exceed those of most developing countries, the emissions of large developing countries are projected to continue to rise sharply. ${ }^{44}$ In 2005, China surpassed the United States as the world's largest emitter of $\mathrm{CO}_{2}{ }^{45}$ in 2013 , its share of global emissions was $29 \%$, compared to the United States' 15 \% and the European Union's (EU) 11 \%. In per capita terms, China's emissions (7.4 tonnes) were virtually on par with those of the EU (7.3 tonnes), but both remained

\footnotetext{
${ }^{37}$ See Ann M. Simmons, "One looming consequence of climate change: small islands nations will cease to exist," Los Angeles Times (November 16, 2016), at http://www.latimes.com/world/global-development/la-fg-global-hughsealy-qa-snap-20161115-story.html (accessed April 13, 2017).

${ }^{38}$ See US Environmental Protection Agency, "International Climate Impacts," at https://www.epa.gov/climateimpacts/international-climate-impacts (accessed April 13, 2017).

${ }^{39}$ David A. King, "Climate Change Science: Adapt, Mitigate or Ignore?" (2004) 303 Science (January 9, 2004), 176177.

40 See American Security Project, Global Security Defense Index on Climate Change (2014), at http://www.americansecurityproject.org/climate-energy-and-security/climate-change/gsdicc/ (accessed April 13, 2017), 1.

${ }^{41}$ See Stephen M. Gardiner et al., Climate Ethics: Essential Readings (Oxford: Oxford University Press, 2010); Henry Shue, Climate Justice: Vulnerability and Protection (Oxford: Oxford University Press, 2014).

${ }^{42}$ See FCCC, note 20, preamble ("the largest share of historical and current emissions has originated in developed countries").

${ }^{43}$ Todd Woody, "Here's Why Developing Countries Will Consume 65\% of the World's Energy by 2040," The Atlantic (December 3, 2013), at https://www.theatlantic.com/technology/archive/2013/12/heres-why-developingcountries-will-consume-65-of-the-worlds-energy-by-2040/282006/ (accessed April 13, 2017).

${ }^{44}$ US Energy Information Administration, International Energy Outlook 2011 (Washington, DC: September 2011) http://www.eia.gov/pressroom/presentations/howard 09192011.pdf, (accessed April 13, 2017), 139-46.

${ }^{45}$ See World Resources Institute (WRI), "CAIT Climate Data Explorer," at http://cait.wri.org (accessed April 13, 2017).
} 
significantly below US per capita emissions (16.6 tonnes). ${ }^{46}$ The effects of climate change, in turn, are likely to disproportionately affect developing countries, many of which are especially vulnerable to them. ${ }^{47}$ However, industrialized countries have vastly larger economic and technological capacity -- not only to mitigate greenhouse gas emissions, but also to adapt to its consequences. Finally, whatever the actual disparities in contributions to and effects of climate change on individual countries, the gulf between radically different perceptions of the problem is not easily bridged. Many developing countries see climate politics as part of a larger pattern of historical and economic injustices, and so have demanded that industrialized countries bear the primary burden of combating climate change. In turn, many industrialized countries have insisted on developing country participation as a matter of pragmatic problem solving, or even "fairness." ${ }^{\text {"8 }}$

And then there are all of us, and how we prioritize and decide as individuals and societies. Here lies an important part of the governance challenge: how to prompt states, political leaders, local communities and individuals to prioritize and actually tackle the climate challenge? According to some, it is extremely difficult or even impossible to do so. For example, some commentators suggest that human psychology and the challenges inherent in collective action impede effective climate policy, ${ }^{49}$ others claim that democracies, in particular, are incapable of dealing with climate change. ${ }^{50}$

Given the multitude of state and non-state actors implicated in the causes and effects of global climate change, any one of the dimensions described above would qualify as complex - as akin to "traffic." The amalgam of diverse but interconnected problem dimensions, however, makes the whole of the climate challenge exponentially more complex yet. Competing impulses, non-linear behaviour, and collective action challenges abound as traffic converges, proceeds and stalls on multiple, criss-crossing levels and

\footnotetext{
46 Jos G.J. Olivier, Greet Janssens-Maenhout, and Jeroen A.H.W. Peters, Trends in global CO2 emissions - 2014 Report (The Hague: PBL Netherlands Environmental Assessment Agency, 2014) http://edgar.jrc.ec.europa.eu/news docs/jrc-2014-trends-in-global-co2-emissions-2014-report-93171.pdf (accessed April 13, 2017), 24.

47 IPCC, Climate Change 2014: Impacts, Adaptation and Vulnerability (Cambridge: Cambridge University Press, 2014), SPM 30-32.

${ }^{48}$ See J. Timmons Roberts and Bradley C. Parks, A Climate of Injustice: Global Inequality, North-South Politics, and Climate Policy (MIT Press, 2007), ch. 5.

49 See Andreas Glöckner, "Psychology and Disaster: Why We Do Not See Looming Disasters and How Our Way of Thinking Causes Them," (2016) 7 Global Policy 14-21; Scott Barrett, "Collective Action to Avoid Catastrophe: When Countries Succeed, When They Fail, and Why," (2016) 7 Global Policy 40-49.

50 Jo Confino, "It is profitable to let the world go to hell," The Guardian, 19 January 2015 <http://www.theguardian.com/sustainable-business/2015/jan/19/davos-climate-action-democracy-failure-jorgenranders> (accessed March 16, 2016).
} 
across multiple, potentially incompatible, modes of transport. So, how can international law contribute to managing this degree of complexity, keeping the "traffic" going and avoiding a catastrophic "crash"? । now turn to that question, beginning with reflections on the concept of the international rule of law.

\section{The International Rule of Law}

Law is commonly associated with stability and predictability. At the same time, law must be capable of accommodating or even guiding change. ${ }^{51}$ These two dimensions are closely intertwined. Indeed, law's resilience is in important part contingent on its ability to respond to change without compromising the rule of law. This interplay assumes particular importance in the context of the challenges posed by complex problems. In my work with Stephen Toope, I have developed an "interactional" understanding of international law that I believe is helpful in thinking through these questions. ${ }^{52}$ We borrow the concept of "interactional law" from Lon Fuller. He used the term to highlight the limitations of "the prevailing conception of law as a one-way projection of authority, ${ }^{\prime 53}$ and the importance of appreciating law as closely tied to its social context. ${ }^{54}$ The interactional account highlights that, whether particular norms are "stable" or undergo "change," international law is inherently dynamic. Like all law, international law is never simply the law "on the books," but "lives" through continuous practices (e.g. implementation, interpretation, justification, contestation) that reinforce existing norms, or develop or even shift them over time. ${ }^{55}$

Our framework posits, first, that legal norms arise in the context of social norms based on shared understandings. ${ }^{56}$ Second, building on Fuller, we suggest that what distinguishes law from other types of social ordering is adherence to specific criteria of legality, widely associated with "the rule of law": generality, promulgation, non-retroactivity, clarity, non-contradiction, not asking the impossible, constancy, and congruence between rules and official action. ${ }^{57}$ When norm creation meets these criteria and, third, is matched with norm application that also satisfies them - when there exists what we call a

\footnotetext{
${ }^{51}$ See, generally, Roscoe Pound, Interpretations of Legal History (1923), at 1.

52 Brunnée and Toope, Legitimacy and Legality, note 31.

53 Lon L. Fuller, The Morality of Law, Rev. ed. (New Haven: Yale University Press, 1969), at 221.

54 See Lon L. Fuller, "Human Interaction and the Law" American Journal of Jurisprudence 14:1, reprinted in Kenneth

I. Winston (ed.), The Principles of Social Order: Selected Essays of Lon L. Fuller, Rev'd ed. (Oxford: Hart, 2001), 211.

55 See also Krieger and Nolte, "The International Rule of Law," note 30, at 13, 18.

${ }^{56}$ Brunnée and Toope, Legitimacy and Legality, note 31, at 56-65.

${ }^{57}$ Fuller, Morality of Law, note 53, at 39, 46-90.
} 
"practice of legality" - actors are able to organize their interactions through law. ${ }^{58}$ This focus on internal traits and practices of legality is useful in the present context. The requirements of legality transcend the "sources" of international law, disciplining legal interaction on the basis of both formally binding rules and the "soft" norms that increasingly shape interactions amongst a widening range of international actors.

This conception of the rule of law, meant to ensure that diverse priorities could be freely pursued by autonomous actors under the law, ${ }^{59}$ has purchase in the international arena as well. ${ }^{60}$ Fuller's canon of legality was concerned with constituting as well as limiting governmental authority. But congruence and reciprocity between citizens and government were at the core of his conception of the rule of law. ${ }^{61}$ That is, only when the law and its application meet the requirements of legality will it be able to guide citizens' decision-making, thereby also limiting what governments can do through law. This version of the rule of law holds an important insight for international law: even when a legal order appears to be hierarchical, it is in fact horizontal in important respects. Hence, a horizontal order like international law, even without the features commonly associated with domestic law, can be a legal order. And precisely because states, as the still-dominant international actors, occupy multiple roles at once (subjects, lawmakers and administrative agencies), transposing the concept of the rule of law to the international level is not only possible but necessary. ${ }^{62}$ In this setting, as also highlighted in the framing paper for this volume, its operation is best understood broadly - as enabling and constraining justification and contestation, rather than as concerned only with ensuring compliance or limiting authority. ${ }^{63}$

The conception sketched out above has particular strengths when it comes to imagining a foundation for a rule of law that can operate in today's deeply diverse international society. The requirements of legality that underpin the interactional international law framework are primarily formal in nature: ${ }^{.4}$ they constrain the ability of all actors, including powerful actors, to proceed in arbitrary or entirely self-

\footnotetext{
58 Brunnée and Toope, Legitimacy and Legality, note 31, at 7, 27-28, 70-77.

59 Ibid., at 24.

60 The following paragraphs draw from Brunnée and Toope, "Interactional Legal Theory," note 31.

${ }^{61}$ Fuller, Morality of Law, note 53, at 19-27.

62 See Jeremy Waldron, "The Rule of International Law," (2006) 30 Harvard Journal of Law \& Public Policy 15.

${ }^{63}$ See Krieger and Nolte, "The International Rule of Law," note 30, at 9, 12-13.

${ }^{64}$ Although Fuller referred to the requirements as "procedural," the term "formal" arguably better captures their nature and function.
} 
serving fashion, but they do not themselves entail thick substantive commitments. ${ }^{65}$ Such a substantively thin conception of the rule of law, built around formal requirements of legality and upheld by collective practices of legality, is particularly suited to international society's highly variegated political context. Nothing precludes actors from promoting substantive understandings in international law. But a "thin" international rule of law is possible and, arguably, its requirements are all the more important in the absence of shared substantive values and goals, ${ }^{66}$ or as actors work towards shared substance. These features of the international rule of law assume heightened importance when it comes to international law's encounter with complexity. Furthermore, as we have seen, complexity thinking calls for relational, process-oriented and dynamic approaches. The interactional understanding of legality, focused on the traits of legal norms and emphasizing practices of legality, serves to highlight law's innate capacity to grapple with these postulates. However, as the next section will illustrate, this basic capacity is weaker or stronger, depending on the legal context (custom or treaty-based; formal or informal) in which the relevant practices occur.

\section{The Evolution of International Environmental Law}

How do international lawmaking and legal practice contribute to tackling complex environmental problems, and with what implications for the international rule of law? I begin with brief observations about customary law and "soft" law. I suggest that customary law, broadly speaking, is less suited to managing complexity than treaty-based law. Hence, the bulk of the discussion is focused on treatybased regimes, which anchor international law's most important responses to complexity and can accommodate formal ("hard") as well as informal ("soft") approaches to standard-setting and accountability.

\section{a. Customary Law}

How does the customary law framework measure up to the challenges posed by complex problems on the one hand, and the demands of the rule of law on the other? Seen from the latter vantage point, customary law has a number of advantages. The customary lawmaking process is a subtle combination of unilateral acts - the practices of legality referred to above - and collective action - the requirement that practice must be widespread in order to serve as foundation for custom. Hence, although

\footnotetext{
${ }^{65}$ See also Jan Klabbers, "Constitutionalism and the making of international law: Fuller's procedural natural law," (2008) 5 No Foundations 84-112.

${ }^{66}$ See Martti Koskenniemi, "The Politics of International Law," (1990) 1 European Journal of International Law 4-32.
} 
customary law is inherently dynamic, it is also far more stable than one might assume at first glance. States' practices and legal opinions tend to maintain existing rules, and initiating a shift in the practices and views of a sufficient number of states to generate a new customary norm is relatively difficult. Furthermore, due to these features of the lawmaking process, customary rules tend to provide broadly textured ground rules for interaction. Customary law, therefore, provides a predictable framework of generally applicable rules that are unlikely to make impossible demands and likely to satisfy the constancy, non-contradiction and non-retroactivity requirements. However, although the diffuse, fluid nature of the customary lawmaking process does not negate promulgation and clarity, it does make it harder to identify the precise point at which law arises than do treaty-based processes, with their emphasis on written terms and detailed rules on entry-into-force. ${ }^{67}$

Because it provides open-ended "meta-principles" rather than highly specific rules, customary law has the capacity to accommodate new or evolving concerns, its relative stability notwithstanding. Thus, the stock of customary international environmental norms has remained remarkably constant over many decades, revolving around the duty to prevent transboundary harm and states' related procedural obligations. ${ }^{68}$ Yet, through its due diligence standard, the harm prevention rule also provides a flexible, adaptable yardstick for state conduct. The requirements of due diligence are inherently contextual, and may change over time and depending on the risks involved..$^{69}$ These features of the harm prevention framework are advantages when it comes to dealing with complex problems, reinforced by the framework's strong emphasis on procedural obligations. ${ }^{70}$ Environmental impact assessment, notification, and consultation each address crucial aspects of any effort to grapple with complex issues like climate change.

\footnotetext{
${ }^{67}$ See Jutta Brunnée, "The Sources of International Environmental Law: Interactional Law," forthcoming in Jean d'Aspremont and Samantha Besson (eds.), The Oxford Handbook on the Sources of International Law (Oxford: Oxford University Press, 2017).

${ }^{68}$ See Island of Palmas Case (Netherlands v. USA), (1928) RIAA II 829; Trail Smelter Case (USA v Canada), (1938/1941) RIAA III, 1905, 1965; Corfu Channel Case (UK v. Albania) (Merits), [1949] ICJ Rep. 4; and Case Concerning Pulp Mills on the River Uruguay (Argentina v. Uruguay), [2010] ICJ Rep. 4.

${ }^{69}$ See Pulp Mills, ibid.; and International Tribunal for the Law of the Sea (ITLOS) (Seabed Chamber), Responsibilities and Obligations of States Sponsoring Persons and Entities with Respect to Activities in the Area (Advisory Opinion), ITLOS Case No. 17, 1 February 2011, at para. 117.

${ }^{70}$ See Pulp Mills, ibid.; Certain Activities carried out by Nicaragua in the Border Area (Costa Rica v Nicaragua) and Construction of a Road in Costa Rica along the San Juan River (Nicaragua v Costa Rica), 16 December 2015, at http://www.icj-cij.org/docket/index.php?p1=3\&p2=1\&case=150 (accessed 9 January, 2017).
} 
Alas, for all these strengths, the customary law framework on its own cannot carry the burden of guiding global climate action. While it can help resolve situations involving transboundary impacts, it would be hard pressed to guide legal interaction between more than 190 states, let alone sub-state or non-state actors. Its conceptual limitations are compounded by the constraints inherent in the general legal framework concerning implementation and dispute settlement. When it comes to harm to the commons or to intergenerational impacts, the harm prevention rule arguably falls short. Although it stands to reason that the harm prevention duty gives rise to an erga omnes obligation in relation to areas beyond national jurisdiction, there is little international practice on this point. ${ }^{71}$ Similarly, although the law of state responsibility envisages circumstances in which states other than those directly injured could invoke another state's responsibility for breaches of obligations owed erga omnes, ${ }^{72}$ practice is lacking. Furthermore, because collective concern issues are by definition polycentric, they do not easily lend themselves to traditional, bilateral dispute settlement. In any event, the most important role for international law in dealing with complex problems is not that of providing for dispute settlement, but that of guiding proactive and long-term collaboration, a role that has been served primarily by treatybased regimes, as we will see below.

This all said, leaving aside its inherent limitations in tackling complex environmental problems, it is important to note that customary international environmental law has not "declined." While the development of new substantive norms may have stalled, there has been an uptick in states' reliance on the procedural and due diligence requirements that flank the no harm rule, and a corresponding trend toward refinement of those requirements. ${ }^{73}$

\section{b. Soft Law}

The broad range of norms and standards grouped together under the rubric of "soft" law has filled some of the conceptual gaps left by customary international environmental law. In one guise, soft law serves as a staging ground of sorts, or a transitional phase on the path towards future custom. ${ }^{74}$ For the time

\footnotetext{
${ }^{71}$ See Daniel Bodansky, Jutta Brunnée and Lavanya Rajamani, International Climate Change Law (Oxford: Oxford University Press, 2017), at 49-51.

${ }^{72}$ See Jutta Brunnée, "International Environmental Law and Community Obligations: Procedural Aspects," in Eyal Benvenisti and Georg Nolte (eds.), Community Interests Across International Law (Oxford: Oxford University Press, forthcoming).

${ }^{73}$ See ibid.

${ }^{74}$ See e.g. Alan Boyle, "Soft Law in International Law-Making," in Malcolm D. Evans (ed.), International Law, $3^{\text {rd }}$ ed. (Oxford: Oxford University Press, 2010), 122, at 134-137.
} 
being, the various concepts that might better reflect the scope and multi-dimensional nature of climate change and other complex problems - notably, common concern, common but differentiated responsibilities, precaution, sustainable development - all find themselves in this transitional phase. ${ }^{75}$ But even if these concepts never "harden" into customary law, they can still shape international conduct. Aside from the effects that such concepts nonetheless may have on the legal reasoning of courts, states and other international actors, ${ }^{76}$ they can serve as normative underpinnings for treatybased approaches to environmental problem solving. In this setting, as guiding principles, they help shape the interpretation and evolution of a given regime. They can also come to be fleshed out in more concrete and issue-specific ways. As I will show in the next section, in the climate regime, the concepts of common concern and common but differentiated responsibilities, among others, have played these roles. $^{77}$

Soft law has also emerged as a normative response in its own right, with an array of norm and standard setting processes that do not aim for formally binding effect. In the context of complex problems, informal norm and standard setting may hold considerable advantages: it is often faster and engenders greater willingness to collaborate and to experiment and adapt; it allows for involvement of, and application to, a wider range of actors than does customary or treaty law; and it may provide for more

creative and potentially more effective accountability processes than formally binding law does. ${ }^{78}$ Finally, as I also illustrated in the next section, in the context of treaty regimes, soft norms, standards and processes can be combined in a range of ways with formally binding modes of legality. From an interactional law standpoint, neither the informality of standard setting and accountability, nor the blending of formality and informality necessarily signal a decline in rule of law terms. What matters most, is the extent to which the norms in question meet the requirements of legality, and are buttressed by practices of legality.

\section{c. Treaty-Based Regimes}

Treaty-based regimes, in building upon emerging collective interest concepts such as the ones mentioned in the preceding section, better capture the true scope of complex environmental issues,

\footnotetext{
75 See Bodansky et al., International Climate Change Law, note 71, at 51-55.

${ }^{76}$ See, e.g., Christine Chinkin, "The Challenge of Soft Law: Development and Change in International Law," (1989) 38 International \& Comparative Law Quarterly 850.

${ }^{77}$ FCCC, note 20, preamble and Article 3. And see Brunnée and Toope, Legitimacy and Legality, note 31, Ch. 4.

78 Pauwelyn et al., note 26.
} 
especially global ones. ${ }^{79}$ For example, irrespective of the legal status of the concept, MEAs have designated particular issues as "common concerns of humankind." The FCCC preamble elaborates on the proposition that climate change is a common concern by acknowledging that its global nature "calls for the widest possible cooperation by all countries ... in accordance with their common but differentiated responsibilities and respective capabilities." 80 This framework provides the normative anchor for the climate regime and accounts not only for its universal membership, but also its resilience in the face of the challenges of collective decision-making. The differentiation dimension of the common responsibility frame too has been instrumental in shaping the evolution of the climate regime. Since its inception, parties have debated how responsibilities should be differentiated. Over time, the regime's approach shifted from stark South-North differentiation, reflected in the Kyoto Protocol, ${ }^{81}$ to the much more nuanced and dynamic differentiation that underpins the 2015 Paris Agreement. ${ }^{82}$

A key strength of MEAs when it comes to tackling complex environmental problems is that they are not one-off agreements between states, but rather open-ended "sets of implicit or explicit principles, norms, rules and decision-making procedures around which actors' expectations converge." 83 The adoption of the underlying treaty thus marks not the endpoint of the international legal process but rather its beginning. MEAs typically establish treaty-bodies for ongoing exchange and negotiation among parties, supported by treaty secretariats that provide an array of administrative services. ${ }^{84}$ They enable the long-term interaction among regime participants that is indispensable in dealing with complex, inherently dynamic, and potentially unresolvable, environmental concerns. As the following discussion will illustrate, treaty-based environmental regimes serve to institutionalize collective responses to complexity and provide for extensive procedural elements, including an array of lawmaking and standard setting, as well as compliance and dispute settlement, processes. Furthermore, MEAs make room for non-state actor involvement.

\footnotetext{
79 This section draws upon Jutta Brunnée, “International Environmental Law and Community Obligations," note 72.

${ }^{80}$ FCCC, note 20 (emphasis added).

${ }^{81}$ Kyoto Protocol, reprinted in (1998) 37 ILM 22.

${ }^{82}$ For an overview of this evolution, see Bodansky et al., International Climate Change Law, note 71, at 26-30.

83 Steven Krasner, "Structural Causes and Consequences: Regimes as Intervening Variables," (1982) 36 International Organization 185, at 186.

${ }^{84}$ See Geir Ulfstein, "Treaty Bodies," in Bodansky et al., Oxford Handbook, note 34, 875-889.
} 


\section{Information Exchange and Scientific Assessment Processes}

Notification, provision of information, assessment and consultation supply the necessary foundation for any effective effort to address a complex concern, as well as for subsequent efforts to monitor the performance of both the regime and individual parties, with a view to making adjustments where needed. MEAs, therefore, require parties to cooperate in research and scientific assessments and to report on their implementation efforts. Typically, MEAs also enshrine detailed procedural requirements, such as guidelines on how to measure performance, or on what kind of information to report in what manner. One important advantage of such treaty-based requirements is that their scope and content can be specified and nuanced far more than is possible under the general due diligence framework of customary international law.

The FCCC and its Kyoto Protocol, with their elaborate "monitoring, reporting and verification" (MRV) requirements, provide a good illustration. ${ }^{85}$ Unlike the Kyoto Protocol, the 2015 Paris Agreement does not contain legally binding emission reduction obligations. ${ }^{86}$ But it nonetheless provides for a "transparency framework" that is intended to hold states accountable for their emissions performance. ${ }^{87}$ Thus, even if the details remain to be developed by the parties, ${ }^{88}$ the Paris Agreement subjects all parties to extensive informational requirements pertaining to their greenhouse gas emissions and calls on developed countries to provide information on their financial, technological and capacity building support to developing countries. The agreement's transparency framework is complemented by a "global stock-take" process, which is designed to assess "collective progress towards achieving the purpose of [the] Agreement and its long-term goals." ${ }^{\prime 89}$

In addition to MRV requirements imposed on treaty parties, many environmental regimes establish or collaborate with international scientific and other expert forums, so as to provide less politicized settings for information exchange and scientific assessment than tend to exist in strictly inter-state contexts. For example, the FCCC established a permanent Subsidiary Body for Scientific and

\footnotetext{
${ }^{85}$ FCCC, note 20, Articles 7.2, 12, 13; Kyoto Protocol, note 80, Articles 5, 7. And see Bodansky et al., International Climate Change Law, note 71, at 148-153, 193-194.

${ }^{86}$ See below, notes 100-106 and accompanying text.

87 Paris Agreement, note 32, Article 13. And see Bodansky et al., International Climate Change Law, note 71, at 249-251.

88 Paris Agreement, ibid., Article 13.13.

${ }^{89} \mathrm{Ibid} .$, Article 14. And see Bodansky et al., International Climate Change Law, note 71, at 251-253.
} 
Technological Advice..$^{90}$ The regime also draws upon the expertise of the Intergovernmental Panel on Climate Change (IPCC), which operates under the auspices of the World Meteorological Organization and the United Nations Environment Programme. ${ }^{91}$ Expert forums such as these are important in building consensus around the scope and urgency of environmental issues and the collective action that is required to address them. Their role in grappling with the complexities of issues like global climate change is an iterative one. Once decisions on the general thrust of collective action are taken, the work of expert bodies turns to supporting the elaboration, refinement, or adjustment of regulatory strategies. This cycle repeats, with no definite endpoint. In the climate regime, the IPCC has been instrumental in bringing about acceptance of the need to keep global warming to "well below $2^{\circ} C^{\prime \prime}$ and to pursue efforts to limit it to " $1.5^{\circ} \mathrm{C}$ above pre-industrial levels." ${ }^{22}$ Indicative of the challenges involved is the fact that it took parties more than twenty years to concretize their shared understanding of the FCCC's objective to avert dangerous climate change, ${ }^{93}$ by including the temperature goals in the Paris Agreement.

\section{Lawmaking Processes}

Lawmaking processes and the further development of a treaty-based environmental regime are usually in the hands of a plenary body, such as a Conference of the Parties (COP). COPs and their subsidiary bodies provide a stable institutional setting for iterative standard setting processes and interlocking engagements between technical experts, policy-makers, and lawyers. They have become central venues for international lawmaking activities around complex environmental problems and their practice reflects the background assumption that decision-making on response action is a collective enterprise.

MEAs also allow for the tailoring of lawmaking processes with a view to striking a balance between the protection of state sovereignty through consent requirements and the need for timely collective action. ${ }^{94}$ Much regime development still occurs through ordinary consent-based processes. ${ }^{95}$ For example, when an agreement is amended, or when an additional treaty, such as a protocol, is adopted,

\footnotetext{
${ }^{90}$ FCCC, note 20, Article 9.

${ }^{91}$ See Bodansky et al., International Climate Change Law, note 71, at 98-99.

92 Paris Agreement, note 11, Article 2.1(a).

${ }^{93}$ FCCC, note 20 , Article 2.

${ }^{94}$ See Jutta Brunnée, “COPing with Consent: Lawmaking under Multilateral Environmental Agreements," (2002) 15 Leiden Journal of International Law 1.

95 See above, notes 27-29 and accompanying text. And see Bodansky et al., International Climate Change Law, note 71, at 85-89 (on formal treaty development methods in the climate regime).
} 
individual states are bound only when they consent to these instruments. But the consent requirements have softened. Under many agreements, especially when technical issues are involved, regulatory approaches can be adjusted with effect for all parties, except those that explicitly opt out. ${ }^{96}$ Perhaps more significantly, extensive regulatory detail is adopted through decisions of plenary bodies, without subsequent formal consent by individual states. In most cases, the resulting standards will not be legally binding, although they may well contain mandatory language. For example, under the FCCC and its Kyoto Protocol, provisions on central treaty matters, ranging from inventory and monitoring requirements to the protocol's mechanisms for trading of emission units or reduction credits, were adopted in this way. ${ }^{97}$ The Paris Agreement envisages a similar approach for the adoption of standards concerning key matters such as the communication of and accounting for parties' nationally determined emission reductions, and "common modalities, procedures and guidelines" for monitoring and reviewing parties' commitments. ${ }^{98}$

As the slow evolution of the climate regime illustrates, even formally non-binding standards are subject to difficult negotiations. ${ }^{99}$ Nonetheless, on balance, soft regulatory processes allow speedier regime development and adjustment than processes that involve subsequent ratification by individual states. Equally important is that they facilitate agreement upon collective action and adoption of standards applicable to all parties - an important feature for efforts to address complex environmental concerns.

The Paris Agreement highlights the increasing willingness of states to combine a range of legal approaches so as to maximize the potential for and scope of collective and adaptable standard setting. The Paris "Outcome" consists of a formal treaty, the Paris Agreement, and a COP decision, which adopts the treaty text and supplements it in many key respects. ${ }^{100}$ The Paris Agreement itself contains provisions framed in mandatory terms ("shall") and provisions framed in hortatory or factual terms ("should" or "will"). The most experimental aspect of the Outcome is that, instead of enshrining binding

\footnotetext{
${ }^{96}$ However, in the climate regime, it has proven difficult to use the opt-out approach, due to the sensitive nature of most regime development issues, compounded by the regime's consensus decision-making practice. See Bodansky et al, International Climate Change Law, note 71, at 59, 75-77.

${ }^{97}$ See Brunnée, note 94, at 23-31.

${ }^{98}$ Paris Agreement, note 32, e.g. Articles 4.8, 4.9 and 4.13, and 13.13.

${ }^{99}$ See Bodansky et al, International Climate Change Law, note 71, Ch. 4 (reviewing, inter alia, the negotiation of the 'Marrakech Accords,' a package of COP decisions that fleshed out key aspects of the Kyoto Protocol, and of the 'Copenhagen Accord,' a political agreement that foreshadowed many aspects of the Paris Agreement).

100 For a detailed discussion of the different legal modes in the Paris Agreement, see Bodansky et al, International Climate Change Law, note 71, at 210-222.
} 
emission reduction commitments, it relies on non-legally binding, "nationally determined contributions" (NDCs) by parties. And yet, the Paris Agreement, which entered into force in less than a year, on November 4, 2016, ${ }^{101}$ does not simply give parties free reign in determining their NDCs. All parties have binding obligations to "prepare, communicate and maintain successive" NDCs, ${ }^{102}$ and will be subject to extensive procedural requirements, such as the ones related to performance assessment discussed above. ${ }^{103}$ An interesting legal twist in this latter context is that the Paris Agreement stipulates that parties "shall" communicate their NDCs in accordance with decisions to be adopted by the parties, thereby rendering the content of an otherwise non-binding decision legally binding. ${ }^{104}$ The agreement also stipulates that each party's successive NDCs "will represent a progression" beyond the preceding one. ${ }^{105}$ Yet, to emphasize their "bottom-up" nature, the NDCs themselves are "housed" outside of the agreement - they are to be communicated to the FCCC secretariat and will be published on the FCCC website. ${ }^{106}$

\section{Non-Compliance Procedures}

Another key feature of multilateral environmental regimes has been their approach to compliance. Formal dispute settlement is rare in MEAs, partly because of states' reluctance to resort to it and partly because it may not satisfactorily address the complex, polycentric concerns underlying the agreement. ${ }^{107}$ Quite apart from the diffuse nature of injuries to parties' common interest in compliance with treaty commitments, addressing the underlying environmental concerns requires the greatest possible degree of compliance by the widest possible range of parties. MEAs, therefore, have spawned procedures that assess parties' compliance with their treaty commitments and provide for a range of measures to facilitate or compel compliance.

Facilitation of compliance has been the primary objective of the majority of these compliance procedures. The procedure under the Montreal Protocol on Substances that Deplete the Ozone Layer

101 Paris Agreement, note 32, Articles 20, 21. As at April 16, 2017, the agreement had 143 parties. See FCCC, Paris Agreement - Status of Ratification, at http://unfccc.int/paris agreement/items/9444.php (accessed April 16, 2017).

102 Ibid., Article 4.2.

${ }^{103}$ See above, notes $87-88,98$ and accompanying text.

${ }^{104}$ Paris Agreement, note 32, Article 4.8.

105 Ibid., Article 4.3.

${ }^{106}$ See Decision 1/CP.21, note 32, paras. 13-14.

107 See generally Geir Ulfstein, "Dispute settlement, compliance control and enforcement in international environmental law," in Geir Ulfstein (ed.), Making Treaties Work: Human Rights, Environment and Arms Control (Cambridge: Cambridge University Press, 2007), 115-134. 
neatly encapsulates the facilitative approach, aimed, as it is, at "securing an amicable solution ... on the basis of respect for the provisions of the Protocol."108 This cooperative approach recognizes the fact that, in the context of ozone depletion, non-complying parties were most likely to be states with genuine capacity limitations. But the treaty setting also makes it possible to tailor the non-compliance regime to the features of the underlying concern, and the needs of the parties involved. For example, under the Kyoto Protocol only developed countries and transition countries had emission reduction commitments. ${ }^{109}$ Therefore, capacity building and financial assistance were less appropriate in promoting compliance. Moreover, the Kyoto Protocol regime had certain unique elements, such as its emissions trading mechanisms, which necessitated a tougher approach to compliance. The Kyoto Protocol's compliance procedure, thus, explicitly declared its goals to "facilitate, promote and enforce compliance" with the protocol, ${ }^{110}$ and provided for automatic triggering of the procedure whenever an expert review revealed questions about a party's implementation of its commitments. ${ }^{111}$ In turn, the Paris Agreement, given its reliance on nationally determined, rather than internationally negotiated, emission reduction commitments returns to a "mechanism to facilitate implementation ... and promote compliance." 112 It is to consist of a committee that is "expert-based and facilitative in nature and function[s] in a manner that is transparent, non-adversarial and non-punitive," and that is to be attentive to "the respective national capabilities and circumstances of Parties." 113 The terms of the compliance mechanism, including its triggers and other "modalities and procedures," are to be developed by decision of the parties. ${ }^{114}$

\section{Involvement of Non-State Actors}

A key facet of environmental concerns' complexity is that they are largely caused by and affect actors other than states. As inter-state agreements, MEAs do not accord direct rights or obligations to nonstate actors. The climate regime fits this mould, although the Paris Agreement nonetheless is unusual in

\footnotetext{
${ }^{108}$ See UNEP, Report of the Tenth Meeting of the Parties to the Montreal protocol on Substances that Deplete the Ozone Layer, Annex II: Non-Compliance Procedure (Montreal Protocol NCP), UNEP Dc. OzL.Pro10/9, 3 December 1998, para. 8.

${ }^{109}$ Kyoto Protocol, note 81, Article 3.1, Annex B.

110 Procedures and Mechanisms Relating to Compliance under the Kyoto Protocol (Kyoto Protocol NCP), UN Doc. FCCC/KP/CMP/2005/8/Add.3 (30 March 2006), para. I (emphasis added).

111 Ibid., para. VI.1.

112 Paris Agreement, note 32, Article 15.1.

113 Ibid., Article 15.2.

114 Ibid., Article 15.3.
} 
acknowledging that the rights of a wide range of non-state stake-holders ought to be considered as states respond to climate change. ${ }^{115}$ At a procedural level, however, MEAs have long been accessible to non-state actors, including international organizations, NGOs, or business entities.

An important first dimension of accessibility concerns information about a regime's standard setting and performance monitoring activities. Although transparency through public availability of documents and data may seem ordinary today, contemporary practice does represent a significant departure from the previously closed, strictly inter partes, proceedings. ${ }^{116}$ The impact of shifting attitudes has been amplified by technology - treaty websites now enable non-state actors to access not only legal documents and meeting reports, but also web-casts of plenary sessions, and scientific and technical information, including that compiled pursuant to parties' procedural obligations under the regime. ${ }^{117}$

In addition to such "remote" access to information about the practice of the regime and its parties, MEAs generally provide direct access to meetings of the parties. Along with non-party states, intergovernmental organizations and NGOs can obtain observer status at COP meetings, distribute information or policy papers, meet with official delegations, or report on negotiations. ${ }^{118}$ In a formal sense, decision-making remains entirely in the hands of states, and key negotiating sessions will typically be restricted to state delegations. But non-state actors do have opportunities to provide input into lawmaking processes or even help shape their outcomes. ${ }^{119}$ The climate regime has seen extensive involvement of non-state actors throughout its history, with the numbers of non-state participants at times matching those of UN officials and government negotiators. ${ }^{120}$ The Paris Outcome, however, harnesses a larger shift in global climate governance to a more transnational, multi-level approach. ${ }^{121}$ For example, in cooperation with the FCCC, the Lima-Paris Action Agenda (LPAA) came to catalyze over

\footnotetext{
115 Ibid., preamble.

${ }^{116}$ See Jutta Brunnée and Ellen Hey, 'Transparency and International Environmental Institutions,' in Andrea Bianchi and Anne Peters eds., Transparency in International Law (Cambridge University Press, 2013), 23, at 26.

117 See, e.g. the website of the FCCC, at http://unfccc.int/2860.php (accessed April 16, 2017).

118 On the challenges, see Brunnée and Hey, note 116, at 35-6.

119 Ibid., at 30-37.

120 See Harro van Asselt, "The role of non-state actors in climate compliance," in Jutta Brunnée, Meinhard Doelle and Lavanya Rajamani (eds.), Promoting Compliance in an Evolving Climate Regime (Cambridge: Cambridge University Press, 2012), 149-176, at 149.

121 The UN climate regime is only one of several sites of climate-related governance today. For an overview, see Bodansky et al, International Climate Change Law, note 71, Ch. 8.
} 
10,000 commitments by cities, companies, states, and other non-state actors. ${ }^{122}$ In the lead-up to the Paris meeting, FCCC parties also launched the so-called Non-State Actor Zone for Climate Action (NAZCA), an online platform for registering and tracking climate action pledges by companies, cities, subnational, regions, investors, and civil society organizations. ${ }^{123}$ The Paris Agreement itself merely acknowledges "the importance of the engagements of all levels of government and various actors ... in addressing climate change."124 But the LPAA and NAZCA, were acknowledged and welcomed, respectively, in the COP decision accompanying the Paris Agreement, and the LPAA is to be sustained and scaled-up alongside state actions under the Paris Agreement. ${ }^{125}$

Performance and compliance assessment is one area in which MEAs continue to restrict non-state involvement. The Kyoto Protocol's compliance procedure furnishes a typical example. NGOs may submit "factual and technical information" relevant to the compliance review, ${ }^{126}$ have access to meetings of the compliance bodies unless parties object, ${ }^{127}$ and have access to the findings of the compliance body. ${ }^{128}$ But NGOs cannot trigger the procedure or make formal submissions. In this respect, the Paris Agreement follows suit. None of its three performance assessment processes (transparency framework, global stock-take, compliance mechanism) envisage direct non-state actor involvement. ${ }^{129}$ However, outside of the climate regime, non-governmental organizations have been increasingly active, compiling rigorous and widely respected performance assessments. While not concerned with compliance per se, these assessments did measure states' intended nationally determined contributions in the lead-up to the Paris Agreement against the yardstick of the climate regime's objective and taking into account the principle of common but differentiated responsibilities. ${ }^{130}$ In this way, non-state actors have assumed a role that has been politically and, in the absence of formal emissions commitments under the Paris Agreement, legally difficult for the inter-state regime to take on.

\footnotetext{
122 See Thomas Hale, "'All Hands on Deck": The Paris Agreement and Non-State Climate Action," (2016) 16 Global Environmental Politics $12-22$, at 13.

123 Currently, there are over 12,500 such pledges. See FCCC, "NAZCA - Tracking Climate Action," at http://climateaction.unfccc.int/ (accessed April 16, 2017).

124 Paris Agreement, note 32, preamble.

125 See Decision 1/CP.21, note 32, paras. 117-124.

${ }^{126}$ Kyoto Protocol NCP, note 110, para. VIII.4

127 Ibid., paragraph IX.2

128 Ibid., paragraph VIII.7

${ }^{129}$ Some opportunities for input could, however, be specified as the details of the mechanisms are elaborated. For an assessment, see Harro van Asselt, "The Role of Non-State Actors in Reviewing Ambition, Implementation, and Compliance under the Paris Agreement," (2016) 6 Climate Law, 91-108, at 99-104.

130 See, e.g., WRI, "CAIT," note 45; and Climate Action Tracker, at http://climateactiontracker.org/ (both accessed April 16, 2017). And see van Asselt, "The Role of Non-State Actors," note 129, at 104-107.
} 


\section{The Climate Regime, Complexity and the Rule of Law: An Initial Stock-Taking}

The demands placed upon a treaty-based approach to climate change are considerable. It must provide a hub for legal interactions around a complex, multi-pronged and multi-level problem of global scale, involving all states while also engaging sub-national and non-state actors. The task, furthermore, is to establish a resilient, long-term, but also adaptable regime. By and large, the FCCC has lived up to the postulates of complexity thinking. It provides a stable setting for ongoing interactions between states and other actors, thus reflecting the proposition that complexity is best tackled through "relational" approaches, including through avenues for non-state involvement. It provides a framework of procedural rules and guiding principles for collective action, reflecting the insight that complexity demands process-focused approaches embedded in "organizational patterns." Finally, the structure of the Paris Agreement indicates that the climate regime has grappled with the need for dynamism. Initially, the climate regime developed quickly, using conventional treaty-making methods. The FCCC and Kyoto Protocol were each negotiated in two years (although the Kyoto Protocol took more than seven years to enter into force). ${ }^{131}$ But then the pace of climate negotiations slowed significantly, leaving aside the stream of decisions adopted to flesh out the convention and protocol, and to set the parameters for future negotiations. The Paris Agreement was adopted a full ten years after the entry into force of the Kyoto Protocol. ${ }^{132}$ In the intervening time, the treaty-development process was bedeviled by stark political differences and hindered by the regime's consensus-based decisionmaking. ${ }^{133}$ The Paris Agreement's legal architecture seems better suited to subsequent development. The emphasis on standard setting through COP decisions side-steps the potentially long lag periods between the adoption of a legally binding instrument and its entry-into-force. The reliance on "nationally determined contributions," in turn, altogether obviates the need for international emission standard-setting.

The abovementioned features of the Paris Agreement matter not only from the standpoint of complexity, but also from a "legality" standpoint. The Paris Agreement's approach enhances the climate regime's "generality," seeing as the vast majority of states now have emission-related commitments, ${ }^{134}$

\footnotetext{
131 See Bodansky et al, International Climate Change Law, note 71, at 75.

132 See ibid, Ch. 4 (describing the evolution of the climate regime).

133 See ibid., at 75-77.

${ }^{134}$ As of April 16, 2016, the Paris Outcome had generated contributions accounting for $98.9 \%$ of global carbon emissions. See WRI, “CAIT," note 45.
} 
albeit differentiated in type and stringency. Indeed, the scope for nationally determined differentiation provided by the regime helps ensure that it does "not ask the impossible" of parties. At the same time, the generality dimension is reinforced by that fact that all parties are subject to the same normative expectations, including the requirement of "successive" NDCs (published at the FCCC website), the notions of "highest possible ambition" and "progression over time," and specific reporting requirements. These elements also speak to the legality requirements of "promulgation," "clarity," and "constancy over time." Finally, in combination with the regime's transparency framework and compliance mechanism, the detailed reporting requirements will ensure that the "congruence" of parties' actions with their commitments is systematically assessed.

None of this is to say, of course, that the approach of the Paris Agreement, by definition, is a win for the international rule of law. Indeed, everything will depend on the extent to which parties develop the various elements of the Paris Agreement in keeping with the requirements of legality, and the extent to which robust practices of legality evolve in the implementation of the regime. The fact that the Paris Agreement builds upon the well-established practices of its parent regime certainly bodes well. One might even say that, from a "rule of law" standpoint, the agreement's approach could improve on the "hard law" approach encapsulated in the Kyoto Protocol. That approach resulted in an emission reduction regime that applied to only a small number of parties - it was partial rather than general. Some parties' commitments also turned out to be much harder to meet than originally assumed, even if they were not outright "impossible" to meet. Furthermore, given its five-year commitment period approach, ${ }^{135}$ the Kyoto Protocol could not provide for "constancy over time." A model that relies on formal amendments to develop an emission regime makes future commitments, let alone timely commitments by all states, less than a certainty. In any event, my point here is simply that the Paris Agreement's turn to a blended formal/informal approach does not necessarily entail a decline in legality.

\section{Conclusion}

My survey of the evolution of international environmental law in response to "complex problems" suggests that the rule of law in the field is alive and well. Customary international law provides stable and adaptable ground rules; while there may not have been a major "rise," there also has been no

\footnotetext{
135 See Kyoto Protocol, note 81, Article 3.2. And see Bodansky et al, International Climate Change Law, note 71, at 176-177.
} 
"decline." However, conceptually and in terms of international practice, customary law addresses only a relatively small share of the issues raised by complex problems, especially global problems such as climate change. Soft law can help fill these conceptual and practical gaps, and promote norm development. But in the context of a multifaceted, global challenge, a treaty-based regime is needed to facilitate comprehensive, long-term response action, and to harness the potential power of legally "soft" norms and practices. The climate regime, as I hope to have shown, has proven to be adaptable and resourceful in its approach to both complexity and legality. The Paris Outcome builds on the accumulated experience of MEAs with non-binding standard setting and review processes. But it also reaches beyond that experience, through a move from "top-down," formally binding, lawmaking to a "bottom-up" regime architecture in which states' commitments to emissions-related actions are not internationally negotiated, but nationally determined.

The Paris Outcome may signal a shift in the role of formally binding treaty law in the face of complexity, at least in the climate change context. The role of treaty law appears to be to enshrine the goals, principles and procedures that serve to underpin and support substantive commitments. In this way, some observers have argued, formally binding law now "orchestrates" rather than "regulates" international action, including actions by non-state actors. ${ }^{136}$ In and of themselves, these shifts do not signal a decline of international rule of law in the treaty setting. Rather, the evolution of the global climate regime signals the recognition that complex problems may not be amenable to solutions on the basis of fixed substantive commitments. The main weakness of formal standard-setting processes is that they are not conducive to the indispensable wide participation in complex problem solving, and not "agile" enough to allow repeated cycles of adjustment in light of changes in the myriad factors that make up the climate challenge. But this does not mean that the international rule of law has no role to play. I venture to say that the opposite is true: the requirements of legality that I sketched earlier in this chapter are all the more important in the context of complex problems. In transcending the traditional conceptions of formality and informality, they enable international law to play the perhaps most important role in responding to complexity: to provide a resilient, predictable, but also adaptable, framework for the long-term interaction that is indispensable to enabling reasonably safe "traffic" flow around issues that are resistant to resolution, or even incapable of final resolution.

\footnotetext{
${ }^{136}$ See Matthew Hoffmann, "International Law and Climate Change: Post-Paris Challenges," Remarks, April 5, 2016, at http://www.ccil-ccdi.ca/single-post/2016/03/30/International-Law-and-Climate-Change-PostParis-Challenges (accessed April 16, 2017).
} 